\title{
Paediatric renal tumors
}

\author{
Alexander J Towbin \\ From International Cancer Imaging Society Meeting and 15th Annual Teaching Course (ICIS 2015) \\ London, UK. 5-7 October 2015
}

Pediatric renal masses are uncommon and the differential diagnosis list is made up of a mix of benign and malignant lesions. While there is some overlap in the entities affecting children and adults, the majority of lesions arise in childhood. The child's age, clinical history, and imaging findings all help to distinguish the majority of tumors. The purpose of this interactive session is to review the renal lesions that affect the pediatric population, describe their imaging findings, and discuss how the different lesions are differentiated on imaging. The following tumors will be included:

Benign tumors

1. Nephroblastomatosis

2. Metanephric adenoma

3. Multilocular cystic nephroma

4. Angiomyolipoma

Malignant tumors

1. Wilms tumor

2. Renal cell carcinoma

3. Clear cell sarcoma

4. Mesoblastic nephroma

Published: 2 October 2015

doi:10.1186/1470-7330-15-S1-037

Cite this article as: Towbin: Paediatric renal tumors. Cancer Imaging 2015 15(Suppl 1):037.
Correspondence: alexander.towbin@cchmc.org

Cincinnati Children's Hospital, Department of Radiology, Cincinnati, Ohio 45229, USA original work is properly cited. The Creative Commons Public Domain Dedication waiver (http://creativecommons.org/publicdomain/ zero/1.0/ applies to the data made available in this article, unless otherwise stated. \section{and take full advantage of:}

- Convenient online submission

- Thorough peer review

- No space constraints or color figure charges

- Immediate publication on acceptance

- Inclusion in PubMed, CAS, Scopus and Google Scholar

- Research which is freely available for redistribution

Submit your manuscript at Submit your manuscript at
www.biomedcentral.com/submit C BioMed Central 